\title{
A human infection case with avian-origin H10N3 influenza virus
}

\author{
Jisheng Jing ${ }^{1 \#}$, Longyu Wang ${ }^{2,3 \#}$, Guocheng Wang ${ }^{1 \#}$, Zaodong Dai ${ }^{1}$, Weigang Ren ${ }^{2,3}$, Changhua Yi $^{2,3}$, \\ Jie $\mathrm{Wei}^{2,3}$, Chuanjun $\mathrm{Xu}^{4}$
}

${ }^{1}$ Department of Infectious Diseases, Jurong People's Hospital, Jiangsu University, Zhenjiang, China; ${ }^{2}$ Public Health and Therapy Center of Nanjing, Nanjing, China; ${ }^{3}$ Nanjing Infectious Diseases Clinical Medical Center, The Second Hospital of Nanjing, Nanjing University of Chinese Medicine, Nanjing, China; ${ }^{4}$ Department of Radiology, The Second Hospital of Nanjing, Nanjing University of Chinese Medicine, Nanjing, China

"These authors contributed equally to this work.

Correspondence to: Chuanjun Xu. Department of Radiology, The Second Hospital of Nanjing, Nanjing University of Chinese Medicine, Nanjing 210003, China. Email: xchuanjun@163.com; Changhua Yi; Jie Wei. Public Health and Therapy Center of Nanjing, Nanjing 211113, China; Nanjing Infectious Diseases Clinical Medical Center, The Second Hospital of Nanjing, Nanjing University of Chinese Medicine, Nanjing 210003 , China. Email: chhuayi@sina.cn; weijie615@126.com.

Submitted Jun 07, 2021. Accepted for publication Jun 18, 2021.

doi: 10.21037 /qims-21-592

View this article at: https://dx.doi.org/10.21037/qims-21-592

\section{Introduction}

Avian $\mathrm{H} 10 \mathrm{~N} 3$ influenza virus has been circulated in waterfowl and territory poultry for several decades in eastern and southern Asia $(1,2)$. So far, there has been no reported outbreak of $\mathrm{H} 10 \mathrm{~N} 3$ avian influenza virus in poultry farm or wild field. However, the virus spillover from the natural reservoir into human is still a concern for public health. Hereby, we report the first case of human infection with avian H10N3 influenza virus (Figure 1).

\section{Case presentation}

All procedures performed in studies involving human participants were in accordance with the ethical standards of the institutional and/or national research committee(s) and with the Helsinki Declaration (as revised in 2013). Written informed consent was obtained from the patient and his family.

A 42-year-old male patient was admitted to the Jurong People's Hospital in Zhenjiang city of Jiangsu Province, China, on April 26, 2021, because of fever, productivecough, fatigue for one week and shortness of breath for one day. Three days before admission, the patient presented to another local primary health care facility. A chest computed tomography (CT) showed right lung abnormalities. The patient was treated as community-acquired pneumonia with piperacillin/tazobactam; however, the clinical symptoms did not improve. The patient was then transferred to the Jurong People's Hospital due to unremitting fever with a maximal body temperature of $38.6^{\circ} \mathrm{C}$, and exacerbation of respiratory symptoms. The patient did not report any underlying illness except for hypertension. He was not currently smoking nor a drinker, and had not recently contacted patients who had influenza-like illness. At the time of admission, physical extermination revealed a body temperature of $37.6^{\circ} \mathrm{C}$, a pulse rate of 136 beats per minute and a respiratory rate of 20 breaths per minute. The systolic pressure and diastolic pressure were 135 and $91 \mathrm{mmHg}$. Crackles were audible in both lungs. Blood tests showed leukopenia, hyperglycemia (blood sugar level $17.52 \mathrm{~mol} / \mathrm{L}$, normal range, 3.50$6.44 \mathrm{~mol} / \mathrm{L})$, and elevated lactate dehydrogenase $(1,847 \mathrm{U} / \mathrm{L}$; normal range, 313-618 U/L), C-reactive protein (65.9 mg/L; normal range, $0.068-8.2 \mathrm{mg} / \mathrm{L}$ ), procalcitonin (0.495 ng/mL; normal range, $0.00-0.06 \mathrm{ng} / \mathrm{L}$ ), and D-dimer ( $9.25 \mathrm{mg} / \mathrm{L}$, normal range, $0.00-0.50 \mathrm{mg} / \mathrm{L}$ ) levels.

A chest CT (Figure 2) showed multiple consolidation and ground glass high-density shadows in the lingual segment of left upper lobe, dorsal segment of left lower lobe and right lower lobe, with the largest lesion in the right lower lung. The consolidation lesion showed air bronchogram sign. No enlarged lymph nodes in the hilar and mediastinum and no pleural effusion was noted. The patient was 


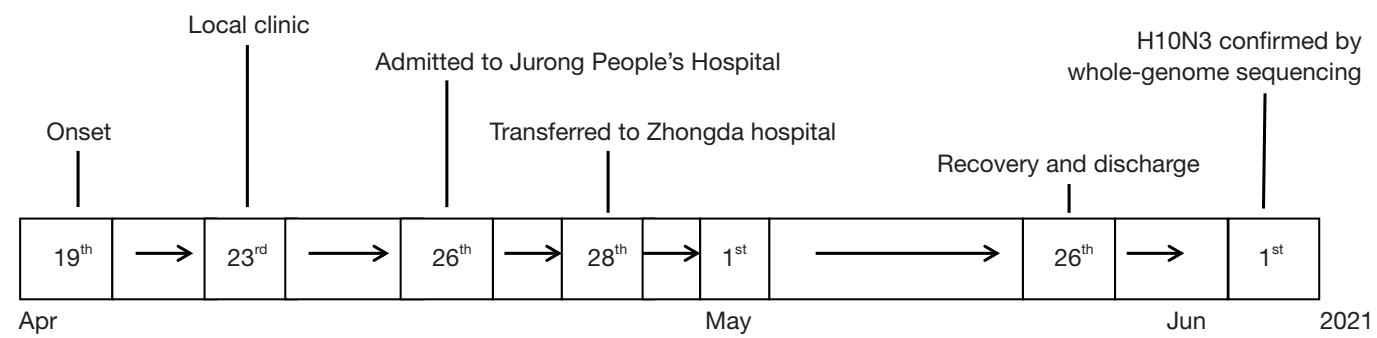

Figure 1 Timeline of the avian-origin H10N3 patient's illness from onset of disease to the time when H10N3 avian-origin influenza virus was confirmed.
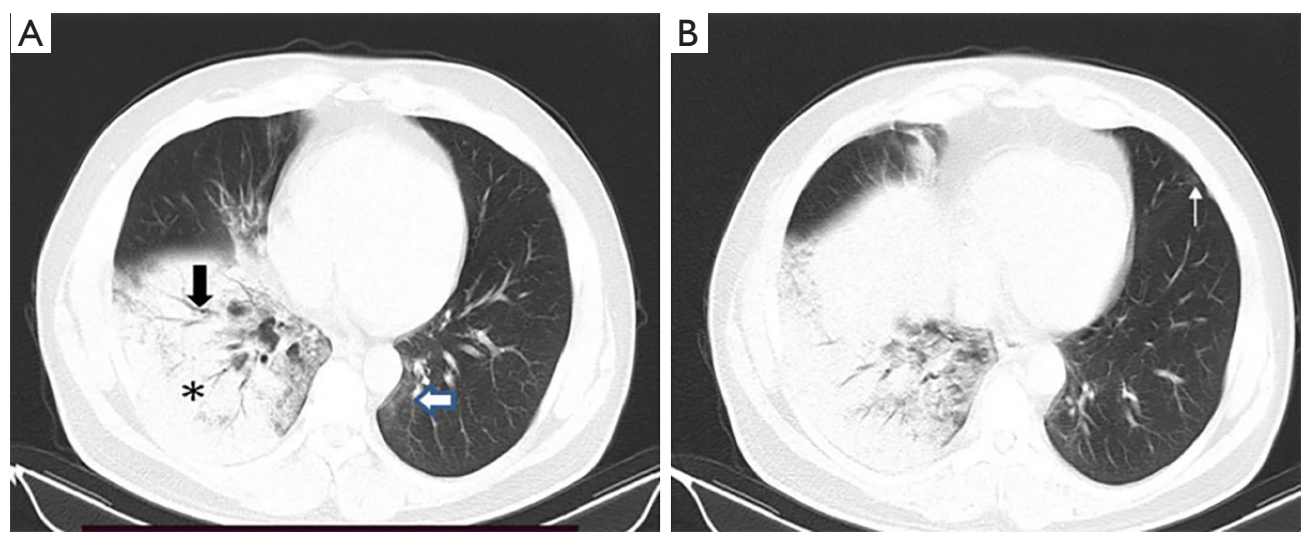

Figure 2 Chest computed tomography scanned on April 26th, 2021. (A) Consolidations and partial ground glass opacities in the right lower lobes $\left(^{*}\right)$ with air-bronchogram sign (black arrow). Ground glass opacities in the dorsal segment of the left lower lobe is also noted (white arrow). (B) Consolidations in the right lower lobes, and ground glass opacities in lingual segment of left lung (white arrow).

treated with ceftriaxone and levofloxacin. There was a sudden progression of the respiratory symptoms during the followed two days. The patient developed dyspnea with an oxygen saturation level of $90.4 \%$ and $\mathrm{PO}_{2}$ level of $51.6 \mathrm{mmHg}$. The patient was then transferred to intensive care unit of Zhongda Hospital affiliated to Southeast University in Nanjing city of Jiangsu Province, China. Influenza A virus-specific nucleic acid was detected from the throat swab sample. The respiratory sample was then sent to the Chinese Center for Disease Control and Prevention, which was confirmed to be positive for avian-origin H10N3 influenza virus (3). After more than a month of treatment with intensive supportive measure (extracorporeal membrane oxygenation) and anti-infectives, the patient recovered and discharged.

An epidemiological investigation was conducted. The patient did not visit any live poultry market during the past 14 days before becoming ill. The working place of this patient's employment, Jurong Yaoxing Safety Glass Co.
Ltd., has many wild birds, most of which were sparrows. Thus far, none of persons that have close contact with this patient has infected with H10N3.

\section{Discussion}

There have been reports of human infections with a number of avian influenza virus, such as H5N1, H7N9, H10N8 and H7N4 influenza viruses (2-5). To our knowledge, this is the first avian influenza in human caused by H10N3 influenza virus. Similar to the reported human infections by H5N1, $\mathrm{H} 7 \mathrm{~N} 9$ and $\mathrm{H} 10 \mathrm{~N} 8$ influenza viruses, $\mathrm{H} 10 \mathrm{~N} 3$ influenza virus could also cause severe pneumonia (6-9). This patient presented with upper respiratory tract symptoms in the early stage of the disease, but in the course of anti-infection treatment, the disease developed into respiratory distress syndrome within days of admission.

The CT findings of $\mathrm{H} 10 \mathrm{H} 3$ avian influenza virus pneumonia in our case included consolidation and multi- 
segmental ground glass opacities. In parts of consolidation, air bronchogram sign was seen. The CT findings of pneumonia by $\mathrm{H} 10 \mathrm{~N} 3$ influenza virus is similar to in other genotypes of avian influenza reported previously (6). As no other cases have been identified thus far, the human-to-human transmission of H10N3 may not be a public concern. It is possible that the underlying diseases (hypertension and diabetes) make the patient susceptible to $\mathrm{H} 10 \mathrm{~N} 3$ infection.

\section{Acknowledgments}

The authors are grateful to the patient and his family for their kind cooperation.

Funding: This work was supported by grants Jiangsu commission of Health: Project of Nanjing Infectious Diseases Clinical Medical Center Construction (NA2021062071) and the Nanjing Science and Technology Development Project (grant \#ZX20200009).

\section{Footnote}

Provenance and Peer Review: This article was a standard submission to the journal. The article did not undergo external peer review.

Conflicts of Interest: All authors have completed the ICMJE uniform disclosure form (available at https://dx.doi. org/10.21037/qims-21-592). The authors have no conflicts of interest to declare.

Ethical Statement: The authors are accountable for all aspects of the work in ensuring that questions related to the accuracy or integrity of any part of the work are appropriately investigated and resolved. All procedures performed in studies involving human participants were in accordance with the ethical standards of the institutional and/or national research committee(s) and with the Helsinki Declaration (as revised in 2013). Written informed consent was obtained from the patient and his family.

Open Access Statement: This is an Open Access article distributed in accordance with the Creative Commons Attribution-NonCommercial-NoDerivs 4.0 International License (CC BY-NC-ND 4.0), which permits the noncommercial replication and distribution of the article with the strict proviso that no changes or edits are made and the original work is properly cited (including links to both the formal publication through the relevant DOI and the license). See: https://creativecommons.org/licenses/by-nc-nd/4.0/.

\section{References}

1. Mikami T, Izawa H, Kodama H, Onuma M, Sato A, Kobayashi S, Ishida M, Nerome K. Isolation of ortho-and paramyxoviruses from migrating feral ducks in Hokkaido. Brief Report. Arch Virol 1982;74:211-7.

2. Wisedchanwet $T$, Wongpatcharachai $M$, Boonyapisitsopa S, Bunpapong N, Jairak W, Kitikoon P, Sasipreeyajun $\mathrm{J}$, Amonsin A. Influenza A virus surveillance in live-bird markets: first report of influenza A virus subtype H4N6, H4N9, and H10N3 in Thailand. Avian Dis 2011;55:593-602.

3. First human case of influenza $\mathrm{A} / \mathrm{H} 10 \mathrm{~N} 3$ virus infection [ER/OL]. Available online: https://www.gisaid.org/ references/gisaid-in-the-news/first-human-case-ofinfluenza-ah10n3-virus-infection/

4. Zhang M, Zhang X, Xu K, Teng Q, Liu Q, Li X, Yang J, Xu J, Chen H, Zhang X, Li Z. Characterization of the Pathogenesis of H10N3, H10N7, and H10N8 Subtype Avian Influenza Viruses Circulating in Ducks. Sci Rep 2016;6:34489.

5. Jin Q, Zhang L, Yang L, Xu L, Yun J, Zhou J, Pan F, Xue $\mathrm{F}, \mathrm{Xu} \mathrm{T}, \mathrm{Wu} \mathrm{J}$. CT scan demonstrations of the globally first case of human infected avian influenza virus (H7N4) pneumonia. Emerg Infect Dis 2018;3:45-8.

6. Lu P. The characteristic of epidemiology and medical imaging in human avian influenza outbreak in China. Electronic Journal of Emerging Infectious Diseases 2017,2:124-6.

7. Gambotto A, Barratt-Boyes SM, de Jong MD, Neumann G, Kawaoka Y. Human infection with highly pathogenic H5N1 influenza virus. Lancet 2008;371:1464-75.

8. Pan H, Zhang X, Hu J, Chen J, Pan Q, Teng Z, Zheng Y, Mao S, Zhang H, King C, F. A case report of avian influenza H7N9 killing a young doctor in Shanghai, China. BMC Infect Dis 2015;15:237.

9. Zhang T, Bi Y, Tian H, Li X, Liu D, Wu Y, Jin T, Wang Y, Chen Q, Chen Z, Chang J, Gao GF, Xu B. Human infection with influenza virus $\mathrm{A}(\mathrm{H} 10 \mathrm{~N} 8)$ from live poultry markets, China, 2014. Emerg Infect Dis 2014;20:2076-9.

Cite this article as: Jing J, Wang L, Wang G, Dai Z, Ren W, Yi C, Wei J, Xu C. A human infection case with avianorigin H10N3 influenza virus. Quant Imaging Med Surg 2021;11(10):4508-4510. doi: 10.21037/qims-21-592 